\title{
Identification of A Liverwort Fossil on Pottery from A Church Excavation in Northern Sudan: Evidence for Moist Paleoenvironment
}

\author{
Yahia F. Tahir a , Ikram M. Ahmed ${ }^{\mathrm{b} *}$, Ibrahim I. Tomsah ${ }^{\mathrm{c}}$, Ibrahim E. Ali ${ }^{\mathrm{d}}$ \\ ${ }^{a}$ Faculty of Art, University Khartoum, Khartoum, Sudan- yahiasd@gmail.com \\ ${ }^{b}$ Faculty of science, University Khartoum, Khartoum, Sudan - ikramahmed3@yahoo.com \\ c Faculty of science, Gassim university, Al-Qassim, Saudia Arabia - b.tomsah@gmail.com \\ d College of science, King Saud University, Riyadh, Saudia Arabia - elagibali@ksu.edu.sai
}

\begin{abstract}
:
This paper aims to document the first record of coalified compression fossil of a liverwort on pottery from a church excavation in the desert, northern Sudan. The outline or surface feature of the fossil is clearly observed. Morphological distortion is minimal while the internal anatomy is not preserved. The shapes of the archaeological specimens are closely similar to the morphology of a Riccia sp collected from the Red Sea state and the Blue Nile bank in Khartoum state. Energy-Dispersive X-ray fluorescence (EDXRF), Scanning Electron Microscopy with Energy (SEM/EDS), and Gas Chromatography and Mass Spectroscopy (GC-Mass) analytical techniques were used to determine the chemical composition of the fossil materials. Higher concentrations were reported for Carbon and Oxygen indicating the organic nature of the materials and also excluded the presence of manganese dentrites which perfectly imitate liverwort fossils. Also n-hexadecanoic acid, dodecanoic acid, tetradecanoic acid, hexadecanoic acid, methyl ester, cis-9-hexadecenoic acid, 9, 12-octadecadienoic acid (z,z)-, methyl ester,tert-butyldimethylsilyl decanoic acid were recorded for the fossil materials. This study also provides additions to the chemical profile for the fresh material from the same genus which provides important data or monitors for the assessment of the chemical or thermal alteration in the corresponding coalified compression fossil.
\end{abstract}

KEYWORDS: Liverwort; Fossil; Paleoenvironment; Desert; Northern Sudan.

\section{INTRODUCTION}

Liverworts are small flowerless green plants with leaf-like stems or lobed leaves, occurring in moist habitats. They belong to the bryophytes which include also mosses and hornworts. Several studies about taphonomic effects on bryophytes have shown that moss and liverwort gametophytes and sporophytes material has a high potential for fossil preservation (Kroken et al., 1996; Kodner and Graham, 2001; Hemsley, 2001; Graham et al., 2004). Bryophytic impressions are relatively rare, but in some can provide taphonomic information, such as by revealing mass accumulations (mats) of Marchantiophyta thalli in a parautochthonous assemblage. Charcoalified bryophyte occurrences are rare: only two moss taxa have been formally described from the Upper Cretaceous (Santonian and Campanian, c. $85 \mathrm{e} 75 \mathrm{Ma}$ ) of Georgia (USA) by Konopka et al, (1997, 1998). About one-third of 449 fossil bryophyte records $(172 ; 38 \%)$ come from amber of Cretaceous or Cenozoic age (Alexandruet al, 2018: 381). This paper aims to document a record of coalified compressions of a liverwort on pottery from a church excavation in the desert, northern Sudan. Morphological and chemical analysis methods were adopted to identify and confirm the nature of fossil materials.

\section{MATERIALS AND METHODS}

\section{1. Materials}

In Ga'ab El Lagia oasis $\left(19^{\circ} 28^{\prime} .356 \mathrm{~N} / 030^{\circ} 16^{\prime} .266 \mathrm{E}\right)$ which is the biggest villages in El Ga'ab depression (Northern Sudan) (Map 1), an ancient church which is probably abandoned since sixteenth has been excavated by El Ga'ab Archaeological Project in season 2017-2018 (Tahir, 2018) Figs.(1 and 2). 16 layers of 10 $\mathrm{cm}$ width were excavated. From all layers, a large number of pots and pottery sherds which show a similar- structured, black compressed materials on their surface were recovered.

\subsubsection{Methods}

The following Standard morphological and chemical analysis methods were adopted in this study to identify the nature of the compressed material on the sherds:

\section{Morphological identification method:}

Morphological identification of the archaeological specimen was done by comparing the outline of the surface feature of the black compressed materials with a closely similar morphology of two species of the plant genus Riccia collected from Erkowit in the Red sea state and the Blue Nile bank in Khartoum state. Delta Optical Smart PRO Microscope with a 5MP sensor was used to obtain magnified images for the examined materials.

\footnotetext{
* Corresponding author

This is an open access under a CC BY-NC-SA 4.0 license (https://creativecommons.org/licenses/by-nc-sa/4.0/)
} 


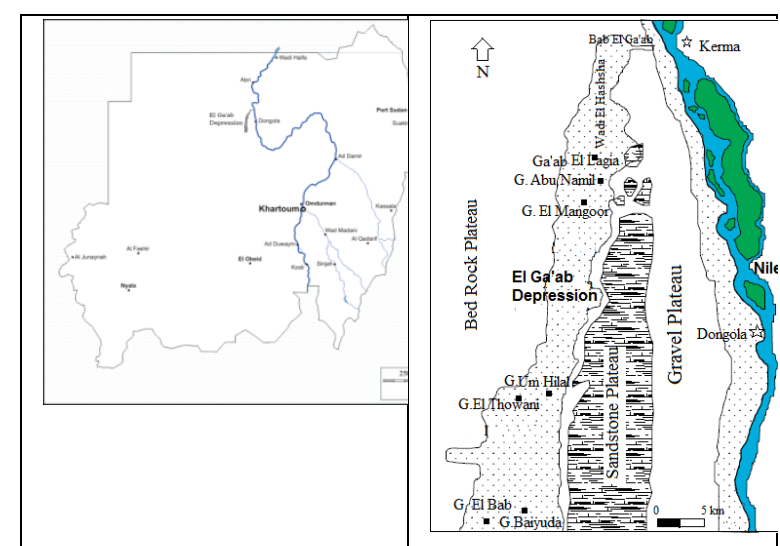

Figure 1. location of El Ga'ab Depression

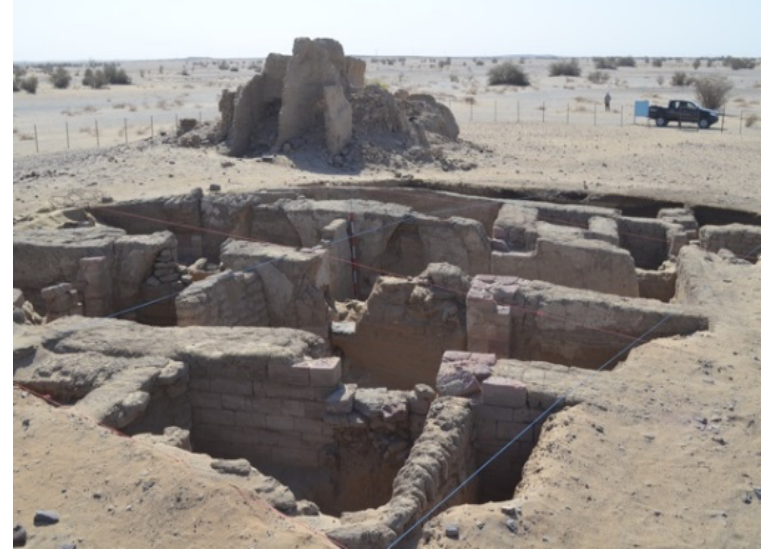

Figure 2. Image showing Ga'ab El Lagia Church Excavation -

\section{Northern Sudan}

\subsubsection{Chemical Identification method:}

\subsubsection{Gas Chromatography and Mass Spectroscopy (GC-Mass):}

Three fractions of methanolic extracts were obtained from powdered samples of the archaeological materials, the fresh reference sample obtained from the Blue Nile bank, and a control sample from the surface of the pottery that free of the fossil. They were investigated using Gas Chromatography and Mass Spectroscopy for the determination of bioactive volatile compounds. GC-MS analysis of the samples was carried out using Shimadzu Make QP-2010 with a non-polar 60 M RTX 5MS Column. Helium was used as the carrier gas and the temperature programming was set with initial oven temperature at $40^{\circ} \mathrm{C}$ and held for $3 \mathrm{~min}$ and the final temperature of the oven was $480^{\circ} \mathrm{C}$ with the rate at $100 \mathrm{C}$ [min.sup.1]. 2- $\mu \mathrm{L}$ samples were injected with splitless mode. Mass spectra were recorded over 35 - 650 amu range with electron impact ionization energy $70 \mathrm{eV}$. The chemical components from the methanolic extracts were identified by comparing the retention times of chromatographic peaks using Quadra pole detector with NIST Library to relative retention indices. Quantitative determinations were made by relating respective peak areas to TIC areas from the GC-MS.

\subsubsection{X-ray fluorescence (XRF) and scanning electron}

\section{microscopy with energy dispersive $\mathrm{X}$-Ray} spectroscopy (SEM/EDS):

These standard techniques were used to characterize the elemental composition of the archaeological materials.

\section{RESULTS}

\subsection{Identification of the fossil based on the morphological} features:

The materials are two- dimensional remains that have been compressed on the surface of pottery from a liverwort Riccia sp. The morphology of the margin and the outline of the surface feature are clearly shown. Morphological distortion is minimal while the internal anatomy is not preserved. The shapes of the archaeological specimens were observed to be closely similar to the morphology of a specimen from the Red Sea state (Fig. 3) and another one from the Blue Nile bank in Khartoum state (Fig. 4).

\subsection{Identification of chemical constituents of the fossil:}

Chemical components separated by the GC-Mass technique in both archaeological and its reference samples proved the presence of different forms of decanoic acid and its derivatives (salts and esters). Undecane and 7, 9-Di-tert-butyl-1-oxaspiro $(4,5)$ deca-6,9-dien are separated from both samples. Archaeological sample was dominated by 7,9-Di-tert-butyl-1oxaspiro(4,5)deca-6,9-dien $(12.14 \%)$ while the reference sample is dominated by e 9,12-Octadecadienoic acid, methyl ester (19.13\%). Fractionations reported for the archaeological samples, the recent fresh reference sample, and a control sample are presented in tables $(1,2$, and 3). (XRF) and (SEM/EDS) analysis showed that the highest concentration is reported for carbon and oxygen using indicating the organic nature of the materials. EDS mapping for both Carbon and manganese excludes the presence of the manganese dentrides which perfectly imitate liverwort fossils Figs. (5,6, and 7)

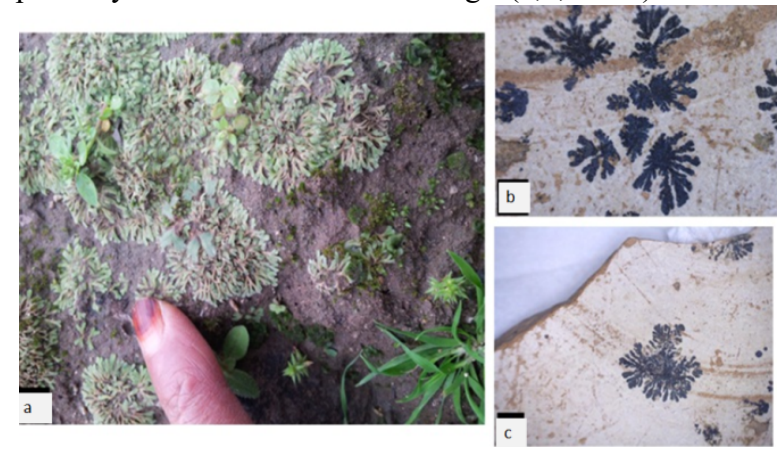

Figure 3. (a) Reference specimen from the Red sea state, (b) and (c) Coalified compression of Riccia sp. from the archaeological site.

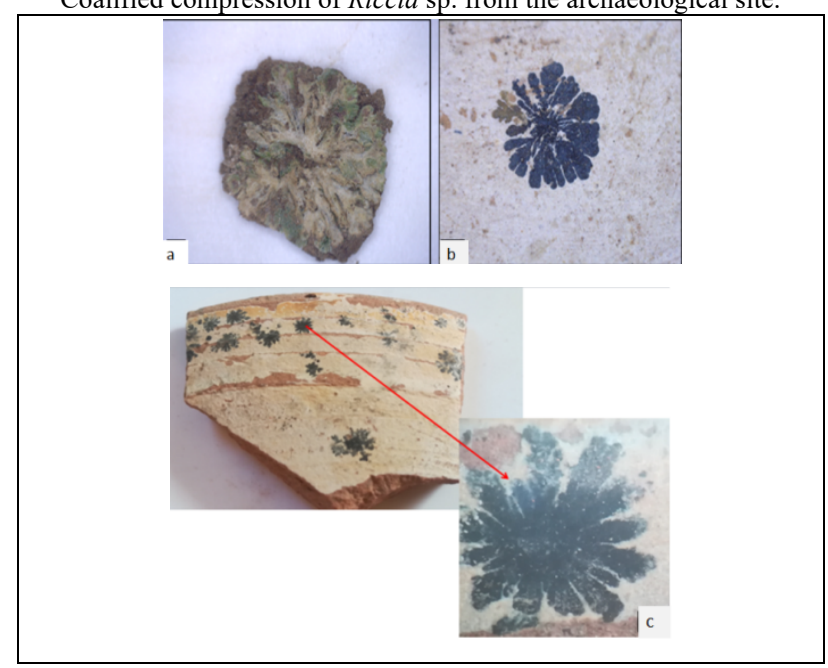

Figure 4. (a) Reference specimen from the Blue Nile bank in Khartoum state (b and c) coalified compressions of Riccia sp. from the archaeological site.

Table 1. Gas Chromatography- Mass Spectrometry characterization of methanol extract of the archaeological material 


\begin{tabular}{|c|c|c|c|}
\hline S.No. & $\begin{array}{l}\text { Retention } \\
\text { time } \\
\text { (Sec.) }\end{array}$ & Name of compound & Area $\%$ \\
\hline 1 & 4.029 & Undecane & 3.21 \\
\hline 2 & 9.467 & $\begin{array}{l}\text { Cyclooctasiloxane, } \\
\text { hexadecamethyl- }\end{array}$ & 6.33 \\
\hline 3 & 11.036 & $\begin{array}{l}\text { Heptasiloxane, } \\
\text { hexadecamethyl- }\end{array}$ & 6.39 \\
\hline 4 & 12.277 & $\begin{array}{c}\text { 7,9-Di-tert-butyl-1- } \\
\text { oxaspiro(4,5)deca-6,9-dien }\end{array}$ & 12.14 \\
\hline 5 & 12.447 & n-Hexadecanoic acid & 4.15 \\
\hline 6 & 12.575 & $\begin{array}{l}\text { Heptasiloxane, } \\
\text { hexadecamethyl- }\end{array}$ & 7.78 \\
\hline 7 & 14.048 & $\begin{array}{l}\text { Heptasiloxane, } \\
\text { tetradecamethyl- ( Mark-V) }\end{array}$ & 6.76 \\
\hline 8 & 15.400 & $\begin{array}{l}\text { Heptasiloxane, } \\
\text { hexadecamethyl- }\end{array}$ & 6.15 \\
\hline 9 & 16.701 & Azacyclotridecan-2-one & 7.32 \\
\hline 10 & 18.090 & $\begin{array}{l}\text { Heptasiloxane, } \\
\text { hexadecamethyl- }\end{array}$ & 5.93 \\
\hline 11 & 18.242 & $\begin{array}{l}\text { Cyclooctasiloxane, } \\
\text { hexadecamethyl- }\end{array}$ & 6.54 \\
\hline 12 & 19.359 & Diiooctyl phthalate & 5.53 \\
\hline 13 & 20.757 & Trans- Traumatic acid & 7.32 \\
\hline 14 & 21.899 & $\begin{array}{l}\text { 9,12-Tetradecadien-1-ol, } \\
\text { acetate (Z,E)- }\end{array}$ & 7.10 \\
\hline 15 & 16.701 & $\begin{array}{l}\text { 3,4-Dihydroxymandelic } \\
\text { acid, 4TMS derivative }\end{array}$ & 6.96 \\
\hline
\end{tabular}

Table 2. Gas Chromatography- Mass Spectrometry characterization of methanol extract of the reference material

\begin{tabular}{|c|c|l|c|}
\hline S.No & $\begin{array}{c}\text { Retention } \\
\text { time ( } \\
\text { Sec.) }\end{array}$ & \multicolumn{1}{|c|}{ Name of compound } & Area\% \\
\hline 1 & 3.525 & 3-Butyn-1-ol & 1.36 \\
\hline 2 & 4.205 & Undecane & 12.37 \\
\hline 3 & 9.021 & $\begin{array}{l}\text { 1,2-Benzenedicarboxylic } \\
\text { acid,2-ethoxy-2-oxo }\end{array}$ & 2.74 \\
\hline 4 & 12.258 & $\begin{array}{l}\text { 7,9-Di-tert-butyl-1- } \\
\text { oxaspiro(4,5)deca-6,9-dien }\end{array}$ & 3.50 \\
\hline 5 & 13.833 & $\begin{array}{l}\text { 9,11-Octadecadienoic acid, } \\
\text { methyl ester }\end{array}$ & 12.81 \\
\hline 6 & 14.033 & $\begin{array}{l}\text { 2-Methyl-6-( 1- propenyl) } \\
\text { piperidine }\end{array}$ & 13.16 \\
\hline 7 & 14.117 & Glycerol 1- palmitate & 15.64 \\
\hline 8 & 14.187 & $\begin{array}{l}\text { 9,12-Octadecadienoic acid, } \\
\text { methyl ester }\end{array}$ & 19.13 \\
\hline 9 & 17.439 & $\begin{array}{l}\text { 9,12- Octadecadienoyl } \\
\text { chloride,(Z,Z)- }\end{array}$ & 14.68 \\
\hline 10 & 17.806 & Allylnonanoate & 4.62 \\
\hline
\end{tabular}

Table 3. Gas Chromatography- Mass Spectrometry characterization of methanol extract of the pottery surface free of archaeological material

\begin{tabular}{|c|c|c|c|}
\hline S.No & $\begin{array}{l}\text { Retention } \\
\text { time(Sec.) }\end{array}$ & Name of compound & Area $\%$ \\
\hline 1 & 6.401 & $\begin{array}{c}\text { Cyclohexasiloxane, } \\
\text { dodecamethyl- }\end{array}$ & 6.50 \\
\hline 2 & 7.884 & 5-tetradecene, (E)- & 5.85 \\
\hline 3 & 8.005 & $\begin{array}{l}\text { Cycloheptasiloxane, } \\
\text { tetradecamethyl- }\end{array}$ & 6.62 \\
\hline 4 & 8.317 & Dodecanoicacid,methyle ester & 2.56 \\
\hline 5 & 8.622 & Dodecanoic acid & 7.46 \\
\hline 6 & 9.032 & Diethyl phthalate & 18.07 \\
\hline 7 & 9.334 & Benzene ( 1-butyloctyl)- & 1.95 \\
\hline 8 & 9.433 & Benzene ( 1-propylnonyl)- & 2.04 \\
\hline 9 & 9.467 & $\begin{array}{c}\text { 3,4-Dihydroxyphenylglycol, } \\
\text { 4TMS derivative }\end{array}$ & 3.67 \\
\hline 10 & 9.636 & Benzene,( 1-ethyldecyl)- & 3.46 \\
\hline 11 & 10.002 & Benzene,( 1-methylundecyl)- & 2.23 \\
\hline 12 & 10.082 & Ethanol, 2-( dodecyloxy)- & 5.96 \\
\hline 13 & 10.236 & Benzene, ( 1-pentylheptyl)- & 3.09 \\
\hline 14 & 10.287 & Benzene,(butyloctyl)- & 3.06 \\
\hline 15 & 10.415 & Benzene, (1- propylnonyl)- & 2.45 \\
\hline 16 & 10.644 & Benzene,(1-ethyldecyl)- & 1.74 \\
\hline 17 & 11.035 & $\begin{array}{c}\text { Hippuric acid, 2TMS } \\
\text { derivative }\end{array}$ & 4.25 \\
\hline 18 & 12.135 & $\begin{array}{c}\text { Heptacosanoic acid, methyl } \\
\text { ester }\end{array}$ & 2.80 \\
\hline 19 & 12.575 & $\begin{array}{c}\text { Heptasiloxane, } \\
\text { hexadecamethyl- }\end{array}$ & 1.73 \\
\hline 20 & 14.049 & $\begin{array}{l}\text { 2,6-Dihydroxybenzoic acid, } \\
\text { 3TMS derivative }\end{array}$ & 1.75 \\
\hline 21 & 15.401 & $\begin{array}{l}\text { Heptasiloxane. } \\
\text { Hexadecamethyl- }\end{array}$ & 1.86 \\
\hline
\end{tabular}

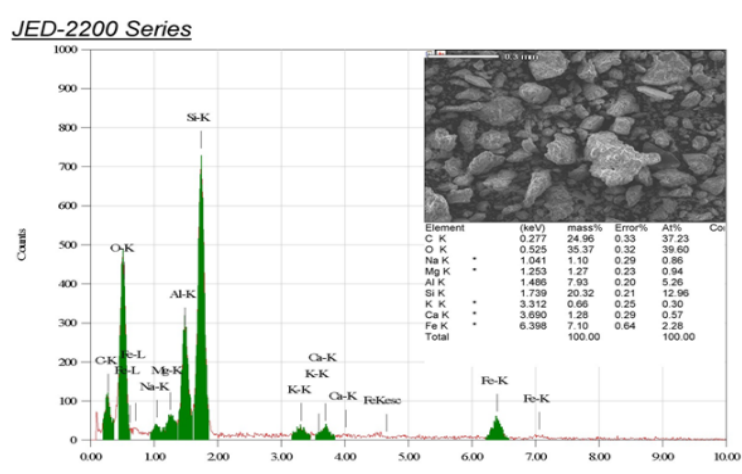

Figure 5. SEM-EDS analysis of a homogenized sample of the archaeological material 

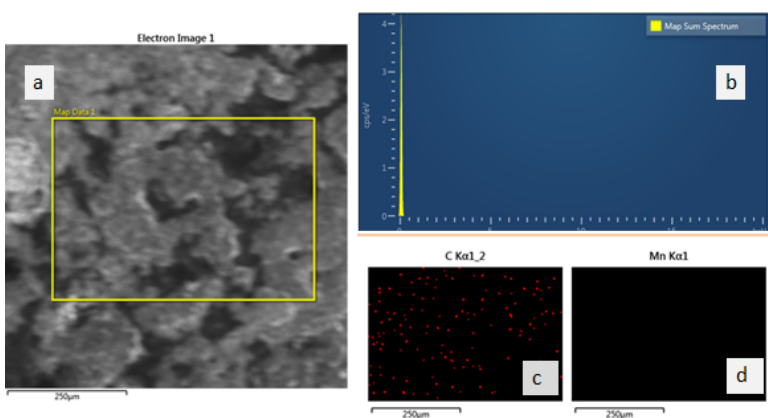

Figure 6. Elemental analysis for the selected area on the surface of the archaeological material: (a) SEM image, (b) EDS spectra, and (c) EDS mapping taken from carbon, (d) EDS mapping taken from manganese

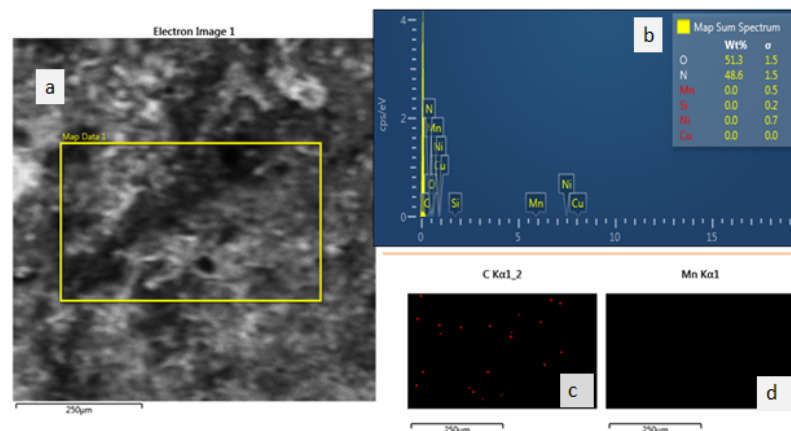

Figure 7. Elemental analysis for the selected area on a surface free of the archaeological material: (a) SEM image, (b) EDS spectra, and (c) EDS mapping taken from carbon, (d) EDS mapping taken from manganese

\section{DISCUSSION}

The possible route of entry of this plant in the studied area is completely natural and it differs from that of other archaeological plant remains. Remains such as residues of crop processing like cereal leaves, pollen and stems fragments are usually encountered at most settlements, either because the processing of the crop took place in this site or brought intentionally as fodder, fuel, or building material. In this case, the place in which the identified liverwort $t$ is found is probably the place in which it was naturally growing. Recording of many separated individuals of this plant in the same place is another evidence of a natural habitat in which the plant was successfully multiplied and spread around the area. Bryophytes tolerate high temperatures (in some species up to $80-100^{\circ} \mathrm{C}$ ) when dry and stay dormant and survive in the very hot desert. The presence of liverwort preserved materials may not available in all archaeological sites reported in the desert of northern Sudan. The Underground water oasis phenomenon in $\mathrm{El} \mathrm{Ga}$ 'ab as a depression is available at a higher level of 1.8-4 m (Tahir, 2012: 102), some intervals after abandoning, making damp habitat where such lower plant propagates. The materials are recovered near the walls of the church where shade, water vapor, and air moving very slowly close to the ground are good humid microclimate required for the plant growth. Rough Surface of the pottery which contains alkaline soil trap and hold the water for a long time providing good germination growth, and sexual reproduction condition for liverwort. Liverwort grows on soil that accumulates in the pottery pits. After the establishment of the first colony, the colony may spread to the surrounding area. (XRF) and (SEM/EDS) analysis results excluded the possibility that the studied remains are manganese dentrites which are inorganic crystals (minerals) that grow on porous materials such as sandstone, slate and ceramics and perfectly imitate liverwort namely Riccia sp.. Recording the presence of decanoic acid derivatives in the Riccian fossil is in harmony with the GC-MS analysis results reported by different authors. Hexadecanoic acid or palmitic acid and pentadecanoic acid in liverwort were reported by Abay et al. (2013), Hexadecanoic acid is also reported by Wankhedet and Manik (2015) n-hexadecanoic acid ,dodecanoic acid, tetradecanoic acid,hexadecanoic acid, methyl ester, cis-9-hexadecenoic acid, 9,12-octadecadienoic acid (z,z)-, methyl ester,tertbutyldimethylsilyl ester, and hexadecanoic acid were reported by Negi (2015).

From this research, identification of this bryophytic fossil will be added to the preservation potentiality of such structurally delicate organisms. Also, characterization of some of the chemical constituents of the studied material is a new data added to the diagnostic paleobiochemical profile of the fossil of this taxon which needs analysis of more specimens from different strata of the genus Riccia fossil. The use of living material from the same genus which is not been subjected to fossilization also provides important data or monitors for the assessment of the chemical or thermal alteration in the corresponding coalified compression fossil. Paleo-chemical data also help in assessing the physical conditions during fossilization such as the presence of thermally labile constituents used to infer the maximum temperature experienced by the fossil. Polymerization reactions are degassing resulting from dehydration or decarboxylation indicated by color change of the organic compound. Results of this research also considers the pottery surface in the desert oasis as a new suitable place to find this type of plant fossil and could be added to the rocks in river deltas, lagoons, along rivers, and in ponds, as reported by Taylor and Taylor, (1993). The organic material compressed on the pottery surface and leaked into pottery surface could be extracted and used for Carbone 14 dating. So dating and knowing the level at which the pottery is found will provide the underground water levels during the obtained date. It provides archeologists the date of burial of the sherds. This is a new method for environmental archaeologists to adopt in paleomicrohabitat reconstruction studies.

\section{CONCLUSION}

The liverwort fossil is preserved on pottery surface under certain circumference as bio-archeological materials. The fossil is a valuable evidence which can be used in many aspects of the archaeological sciences specially environmental archaeology. The organic material compressed on the pottery surface and leaked into the pottery could be extracted and used for Carbone 14 dating. This is a new method for environmental archaeologists to adopt in paleomicrohabitat reconstruction studies.

\section{ACKNOWLEDGEMENTS}

Authors would like to thank all of the 2018- mission members of the archaeological, ecological, and ethnographycal project of El Gaab depression- Western Dongola, Sudan which is kindly funded by the Nubian Archaeological Development orgnization ( Quatar- Sudan).

\section{REFERENCES}

Abay, G., Altun, M., Karakoc, O. C., Gül, F. and Demirtas, I. 2013. Insecticidal activity of fatty acid-rich turkish bryophyte extracts against Sitophilusgranariu Coleoptera: Curculionidae). Combinatorial Chemistry \& High Throughput Screening.16: 806-816.

Alexandru M.F. Tomescu, Benjamin Bomfleur, Alexander C. Bippus 1 and AdolfinaSavoretti. 2018. Why Are Bryophytes So Rare in 
the Fossil Record? A Spotlight on Taphonomy and Fossil Preservation. Transformative PaleobotanyPapers to Commemorate the Life and Legacy of Thomas $\mathrm{N}$. TaylorBook. Edited by Michael Krings, Carla J. Harper, Gar W. Rothwell.

Graham, L.E., Wilcox, L.W., Cook, M.E., Gensel, P.G., 2004 Resistant tissues of modern marchantioid liverworts resemble enigmatic Early Paleozoic microfossils. Proceedings of the National Academy of Sciences USA $101,11025-11029$.

Hemsley, A.R., 2001. Comparison of in vitro decomposition of bryophytic and tracheophytic plant material. Botanical Journal of the Linnean Society 137, 375-384

Kodner, R.B., Graham, L.E., 2001. High-temperature, acidhydrolyzed remains of Polytrichum (Musci, Polytrichaceae) resemble enigmatic SilurianeDevonian tubular microfossils. American Journal of Botany 88, 462-466.

Konopka, A.S., Herendeen, P.S., Crane, P.R., 1998. Sporophytes and gametophytes of Dicranaceae from the Santonian (Late Cretaceous) of Georgia, USA. American Journal of Botany 85, 714-723.

Konopka, A.S., Herendeen, P.S., Smith Merrill, G.L., Crane, P.R., 1997. Sporophytes and gametophytes of Polytrichaceae from the Campanian (Late Cretaceous) of Georgia, USA. International Journal of Plant Sciences 158, 489-499.

Kroken, S.B., Graham, L.E., Cook, M.E., 1996. Occurence and evolutionary significance of resistant cell walls in charophytes and bryophytes. American Journal of Botany 83, 1241-1254.

Negi ,K. 2015.Determination of Biological Activities and Phytochemical Characterization of Selected Bryophytes. $\mathrm{Ph} \mathrm{D}$. thesis Submitted to theG.B. Pant University of agriculture and technology, India.

Tahir, Y. F. 2012. A Holocene Palaeolake in El Ga'ab depression western desert, Northern Sudan. Sahara 23: 99-112.

Tahir, Y.F. 2018. 'The Archaeological, Ethnographical and Ecological Project of El-Ga'ab Depression in western Dongola Reach: Unpublished report on the Fifth season 2018-2019'. Department of Archaeology, University of Khartoum,Sudan

Taylor, Thomas N.; Taylor, Edith L. 1993. The Biology and Evolution of Fossil Plants. Englewood Cliffs, NJ: Prentice Hall. 7-12.

Wankhede, T. B. and Manik, S. R. 2015. GC-MS analysis of the liverwort PlagiochasmaappendiculatumLehm. et Lindenb. International Journal of Chemical and Physical Sciences, 4 Special Issue, 372-376. 